\title{
Therapy of addition for Alzheimer's Disease: combination with galantamine and memantine
}

\author{
Julio Zarra ${ }^{1 *}$, Luisa Schmidt ${ }^{2}$ \\ From $1^{\text {st }}$ International Congress on Neurobiology and Clinical Psychopharmacology and European \\ Psychiatric Association Conference on Treatment Guidance \\ Thessaloniki, Greece. 19-22 November 2009
}

\section{Background}

The efficacy, safety, and tolerability of nootropic cholinergic agent: GALANTAMINE (with a dual mechanism of action on the cholinergic a system) and moderate affinity NMDA - receptor antagonist: MEMANTINE, were assessed taking into account the profile of patients with neurocognitive disorder: Alzheimer's disease, from the clinical aspects and the different classifications.

\section{Materials and methods}

The experience included 380 patients who were enrolled in a prospective, observational, multicenter, and openlabel study to receive $16 \mathrm{mg} /$ day of galantamine and $30 \mathrm{mg} /$ day of memantine for 12 months of treatment of addition.

\section{Results}

The therapeutic response was measured using the Mini Mental State Examination (MMSE), Clinical Dementia Rating (CDR), Alzheimer's Disease Assessment Scale (ADAS-GOG), Functional Activities Questionnaire (FAQ) the Clinical Global Impression Scale (CGI) and the UKU scale of adverse effects taking into account the efficacy, safety and adverse events of the treatment.

\section{Conclusions}

The final results of the study showed that galantamine with addition memantine improves cognition, behavioural symptoms, and the general well-being of patients with cognitive impairment: Alzheimer's disease. The incidence of adverse events was not significant and a very good profile of tolerability and safety was observed.

\footnotetext{
${ }^{1}$ Servicio de Psiquiatría. Hospital Italiano de La Plata. La Plata. Buenos Aires,
} Argentina

\section{Author details}

${ }^{1}$ Servicio de Psiquiatría. Hospital Italiano de La Plata. La Plata. Buenos Aires, Argentina. ${ }^{2}$ Servicio de Salud Mental. Hospital Centenario. Gualeguaychú. Entre Ríos, Argentina.

Published: 22 April 2010

\section{References}

1. Blesa R: Galantamine: therapeutics effects beyond cognition. Dement Geriatr Cogn Disord 2000, 11(suppl 1):28-34.

2. Sramek JJ, Veroff $A E$, et al: The status of ongoing trials for mild cognitive impairment. Expert Opin Inveting Drugs 2001, 10(4):741-752.

\section{doi:10.1186/1744-859X-9-S1-S118}

Cite this article as: Zarra and Schmidt: Therapy of addition for Alzheimer's Disease: combination with galantamine and memantine. Annals of General Psychiatry 2010 9(Suppl 1):S118.
Submit your next manuscript to BioMed Central and take full advantage of:

- Convenient online submission

- Thorough peer review

- No space constraints or color figure charges

- Immediate publication on acceptance

- Inclusion in PubMed, CAS, Scopus and Google Scholar

- Research which is freely available for redistribution

Submit your manuscript at www.biomedcentral.com/submit
C Biomed Central 